\title{
（早稻田大學理工學部萑用化學科荍室）（昭和六年一一月一三日受理） \\ 棕櫚油のカロチンに對する酸性白土の呈色反應 \\ 小林久本・山本研一・阿部二郎
}

緒

言

動植物界に於て黄色乃至橙色を呈し常にリポイド中に存在するカロチノイドなる色素團は油脂類著色の原因 と考へらるつが故に之等色素の跨究並に其脫色除去法等は油脂工業上に於ても與味あり又重要なる事項なり更 に近年ヴィタミン化學に關する研究の進展と共に之等カロチノイド色素とヴィタミンA との關係に就ても多數 の㸴究發表せられ一部學者間にはヴィタミンAはカロチノイド色素の 1 種にしてカロチノイド色素團の代表 的色素たるカロチンはヴィタミンA と全く同樣の榮養學的效果を有することが確認せられつ〉有り（Beth Euler, Hans Euler: Bi ichem. Z., 1928, ¿03,370; 川上行藏氏：理破報、9.290〜302 等) 果して然らばカ口 チンの策養學的地位.も甚だ重要なるものとなり酸性白土に依るカロチンの吸著、呈色反應も亦意義ある事とな れり

乾燥酸性白土が能くカロチンを吸著し 同時に美青色の呈色反應を䉆す事は㐮に著者等の 報告せし所なるが （本誌、昭 4,587〜 591）其際呈色物質はアルコールに依りて容易に抽出せられて橙色の色素となりアルコール を分離せば再び $80 \%$ アルュールに不溶となりカロチンと同一呈色反應を繰り返す事ヴィタミンAに對する酸 性白士の呈色反應（本誌、大 13，937～944，1060～1067） と類似して與味ある點なり若し此際アルュールにて 抽出せし色素が原カロチンと同一物なれば此吸著作用を利用して從來の方法より簡單に諸種物體中より酸性白 土に依りカロチンを抽出し得て甚だ便利なり

從來カロチンは人荟又は唐辛、「クチナシ」の惯等より探取せしが今包渚者等は南洋座棕閝油中にも亦カ口 チンの現存を證明し得て（本誌、1931，34，1118)之ヌカロチン原料として探用し得るを知れり棕櫊油の呈色反

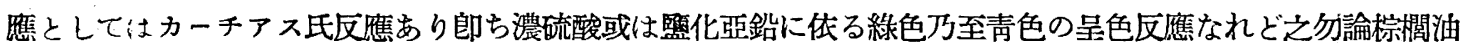
中カロチンの諸種縮合劑に依る呈色反應の一部なり從來知られ居る各喠油脂類に對寸る諸種呈色反應なるもの は油脂類中カロチノイド色素に對寸る呈色反應なる場合も相當多く大豆油、綿實油等に對しても亦酸性白土は 青色呈色反應を䉆し同時に黄色色素の脫色作用を行ひて精製し得る事は暴に著者等が報告せり（早稻田應用化 學會堵、昭 6 , 第 15 號)

著者等は今包南洋産棕櫊油を得て其特異の橙赤色の色相よりカロチンの現存を確めたるを以て次に其呈色反 礁に關し試驗すると同時に該色素を酸性白土に吸著せしめ後之をアルュールに依り抽出して分光學的に其變化 の有無に就て實驗せしを以て此處に其大要を報告せんとす

實 驗 の 部

（I）酸性白土類其他陶土、粘土類の棕櫊油に對寸る定色反應

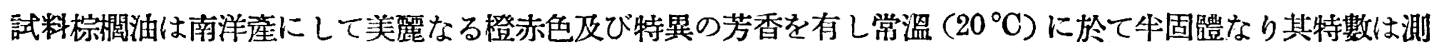
定の結果次の如し

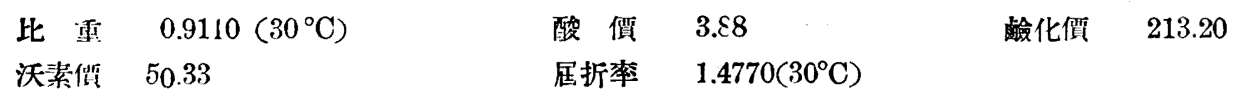




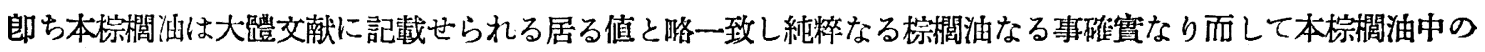

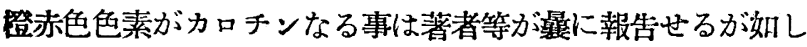

供試酸性白土、陶土類は何れも苗驗に當りて粉未とし 170 メッシ下とし $120^{\circ} \mathrm{C}$ の電氣恒温慒中に 3 時間 乾燥したるものを使詡せり呈色反應試驗法は下記の如し棕櫚油 $20 \mathrm{~g}$ をベンゾール $200 \mathrm{cc}$ に溶解し之を原液 として其 $20 \mathrm{cc}$ を試驗管に取り之に供試白士又は陶士類 $1 \mathrm{~g}$ を加へ常溫に於て 15 分間同一问數振盪し静止 後沈澱白土或は陶土類の色相を檢すると同時に上澄液の色相を比較して其脫色力を觀察したり其の結果は次の 如し

酸性白土に痀すべきものは凡て靑色を呈す但し其色相に濃淡あり濃靑色より淡青色迄のものを順次列記すれ ば次の順序となる
（1）獨逸活性土
(2). 小戶白士 (黃)
(3) 糸魚川白土 (白)
(4) 㫧魯川白土 (黃)
(5) 白崎白土
（6）小戶大澤白土（白）
(7) 網走白土
（8）米國库フロリダ・アース（9）苂城白士
(10）英國举フーラース・アース

白土層の色相は白色のものは靑色呈色反應を示せども黄色乃至赤色のものは其呈色は綠色に近き色相なり故 に精密に呈色反應の强弱を比較せんには寧ろ上澄殘液の色相郎ち其脫色力を比較する方可なり上記實驗に於て は白土類の探取量少しく多量にして (1) (2) (3) (4) は上澄液無色淕明 (5) (6) (7) は殆んど無色 (8) (9) (10)は淡黃色なり

次に非酸性白土類として 白陶土、小金井壤土、珪藻土、長石粉は何れも全く呈色せず苗木陶土、三石蠟

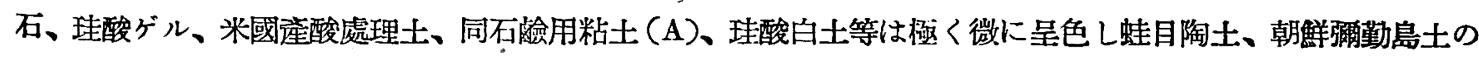
2 種は微に呈色す

婴するに酸性白土屬粘土は何れる棕閖油中の色素を吸著して青色の呈色反應を篇し其呈色反應は脫色力の强 弱に比例与非酸性白土屬粘士は之に反し其呈色反應遥に微弱なり但し或種類の陶土類に於ては呈色反應相當に 强きものあれど斯の如きものは酸性白土に近き性質を具備せるものと考ふるを得べし

\section{（II）呈色反應に及注す溶劑の影響}

次に酸性白土の呈色反應に及ぼす溶劑の影響を見んとして棕闆油各 $1 \mathrm{~g}$ を次の各種溶劑 $10 \mathrm{cc}$ 宛に溶解し

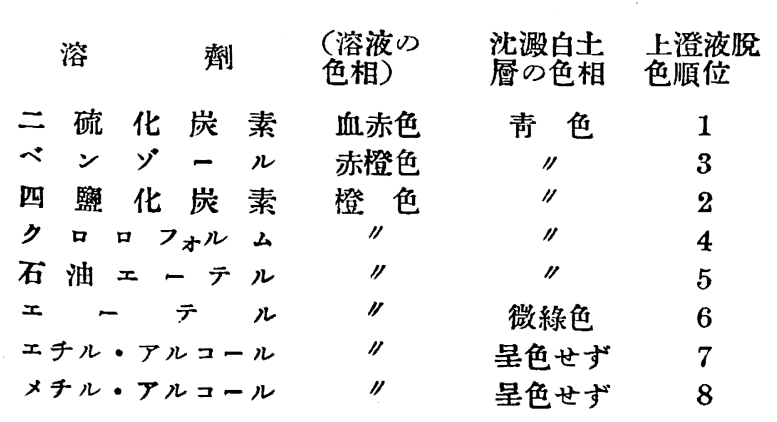
之に乾燥せる小戶大澤白土各 $1 \mathrm{~g}$ 宛を添加し て其呈色反應の强弱並に上澄液の脫色程度を 觀察したり其結果は次の如し但し左表中（溶 液の色椐）は棕櫊油を各溶劑に溶解せる時の 色相にして落考として揭ぐ

溶劑としてアルコール類を使用せる場合は 呈色反應をなさずヌェーテルの場合には其旺 色甚だ弱く微称色を示すに此る此事實は肝油 ジィタミンA、カロチン等に對する酸性白土の呈色反㷳の場合と全く同一にして酸性白土の之等溶訬に對する の著力が棕櫚油中の色素に對する夫れよりも大なる䈔なり 
（III）酸性白土の呈色反應は各種脫水縮合劑の呈色反應と同一なり

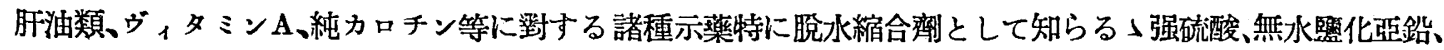
無水監化アルミニウム、五酸化燐、强燐酸、無水第二監化鐵、無水監化アンチモニ 一等の呈色反應は酸性白土 の呈色反應と全く同樣なる事は暴に報告せるが棕橍油の場合も亦之と同一にして郎ち棕櫊油をベンジールヌは

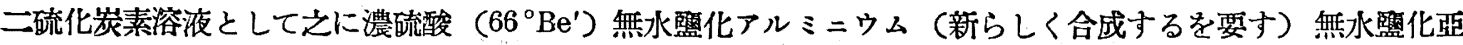
鉆、無水監化第二鐵等を加ふるに何れの場合にも乾燥酸性白土の場合と全く同樣の青色の呈色反應を示す但し 棕櫊油中の色素はカロチンにしてカロチンは一種の炭化水素なれば此場合は呈色反應は冏水作用又は縮合作用 なりと考ふるより寧ろ重合作用に体りて青色に變化すると推察す

\section{(IV) 吸著呈色白土より抽出色素の再呈色反應}

著者等は暴に人荟より結晶したる純カロチンのベンジール泬液を作り酸性白士に泝りて呈色せしめたる青色 物體はアルュール、エーテル等の溶劑に依り抽出せられ之等溶劑を駱逐して再びベンジール溶液とする時は再

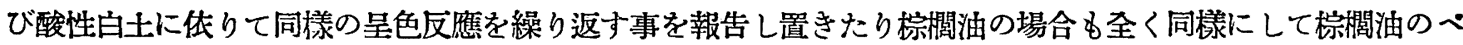
ンデール溶液より酸性白土（小戸大澤白士）に体り呈色せる青色物體は呈色白土層を充分純ベンジールにて洗

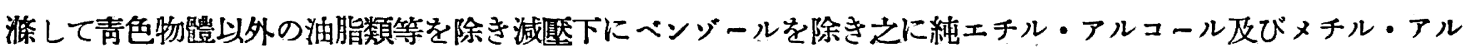
コールを夫々別々の器中にて涯加して充分振盪し呈色物體をアルコールに溶出せしむる時はアルコール溶液の 色相は再び橙赤色の色相を呈し白土の色相は殆んど元來の白色色調に戻るアルコール溶液より減洭下に炭酸瓦 斯氣流中にてアルコールを䮥逐して殘る褐色油狀體に直に二硫化炭素、ペンゾール、石油エーテル等の溶劑を 加へて夫ァの溶液とし之に乾燥酸性白土又は濃硫酸を添加する時は再び青色の呈色反應を呈寸念の䉆め此操作 を 4〜5 四迄連續的に精細に反覆せるも酸性白土に依り呈色せる白士層の色相殆んど各问同一樣なり故に棕櫚 油のペンゾール溶液より酸性白土に依り呈色せる物體はアルコールに依りて容易に抽出せられ此抽出物體は原 棕櫊油同樣數包呈色反應を呈する點より考察するに該抽出色素はカロチンの變化したる物質なるか又は原カ口 チンなるか二者孰れかなり若し原カロチンなれば甚だ䑂味ある事なり此點を確實にせんとして更に人荟より抽 出したる結晶純カロチンのベンゾール溶液を取り之に前同樣小戶大澤白土を加一吸著呈色せしめ後充分ベンッ゙ ールにて洗㹣しペンゾールを殆んど分灕して之に純ェチル・アルュールを加へて振盪し白士層より青色色素を 抽出し減壓下に之等溶劑を分離し後に殘る物㬝に次の如き種々の溶濟を加へて其溶液の色相並に其物體の溶解 の難易を憼察し次に酸性白土及び濃硫酸を加へて其呈色反應の程度を見たり其結果は次の如し

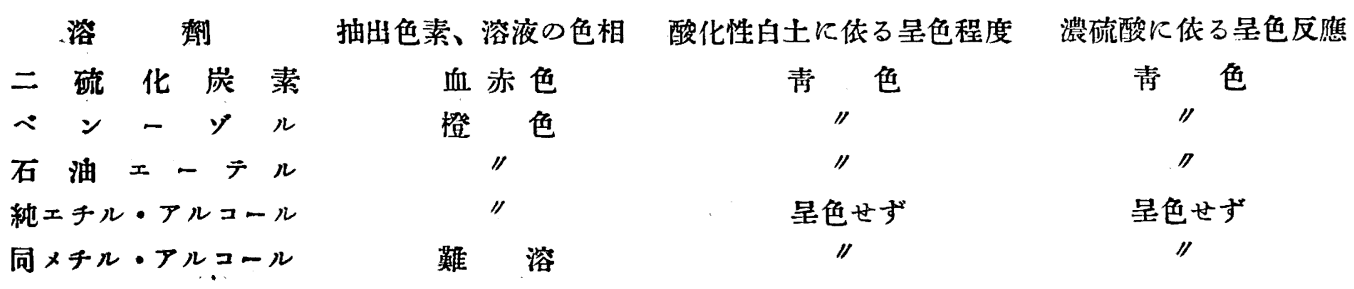

郎ち珯種溶劑の溶液の色相、呈色反應程度等殆んど初めのカロチン溶液の場合と同樣なり.目此操作を數四速 續反覆しても同一結果なり抽出濟がメチル・アルコール、エーテル、アセトンの場合にもェチル・アルコール の場合と全く同樣なり

以上の結果はカロチン、カロチン呈色後抽出色素、棕櫊油呈色後抽出色素は溶劑に對する色相、酸性白土及 
び硫酸に對寸る呈色区㺘の結果よりして同一物質ならんと推察したり唒之を確定せんと欲して次に之等に就て 分光學的に試㩍せり

\section{(V) 抽出色素の分光學的賽驗}

此處に使用したる分光機は前哴标櫚油中のカロチン（本誌、34, 1118）測定に使用したると同樣のアダム・

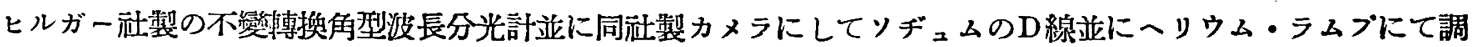
整し置きて後棕櫩油及び純カロチン溶液をぺリー氏管に入れ光源として 5 アムベア直流炭素電弧登を使用して 其吸收帶を測定して吸收曲線を作成したり㱬驗操作の詳細は前報文と同樣なれば省略す

（1）カロチン・ベンゾール溶夜よりアルュールにて抽出せし色素のベンゾール溶液の四收曲線

人荟より抽出したる純カロチンの $5 \times 10^{-5}$ モル・ベンゾール溶液 $30 \mathrm{cc}$ を取り之に小戸大澤白土 $5 \mathrm{~g}$ を加 へ充分吸著呈色せしめ後傾科法に依りてベンゾールを加へて數四洗策して油脂類を除き後ヘンゾールの大部分 を分離し直に純エチル・アルコール50cc を加へて吸著色素を抽出し白土を滤別し後減壓下に炭酸瓦斯を送

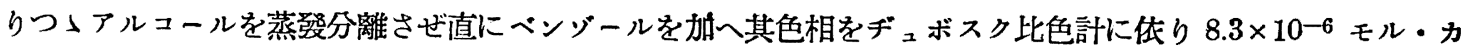
ロチンベンゾール溶液と大略同一となす此溶液に就て前記の如く其吸收帶を測定せし結果は次の如し

第一表 カロチンー白土一アルュール抽出色素(約) $8.3 \times 10^{-6}$ モル・ベンゾール溶液の吸收帶(第一圖)

$\begin{array}{cll}\text { 液層厚さ } & \text { 第一吸收帶 } & \text { 第二吸收帶 } \\ 100 \mathrm{~mm} & 5025 \AA & \\ 90 & 5000- & \\ 85 & 4980 & \\ 80 & 497 \check{-}-4805 \AA & 4700 \AA-4430 \AA\end{array}$

第一圖 カロチンー白土ーアルコール抽出色 素ベンゾール溶液の吸收曲線

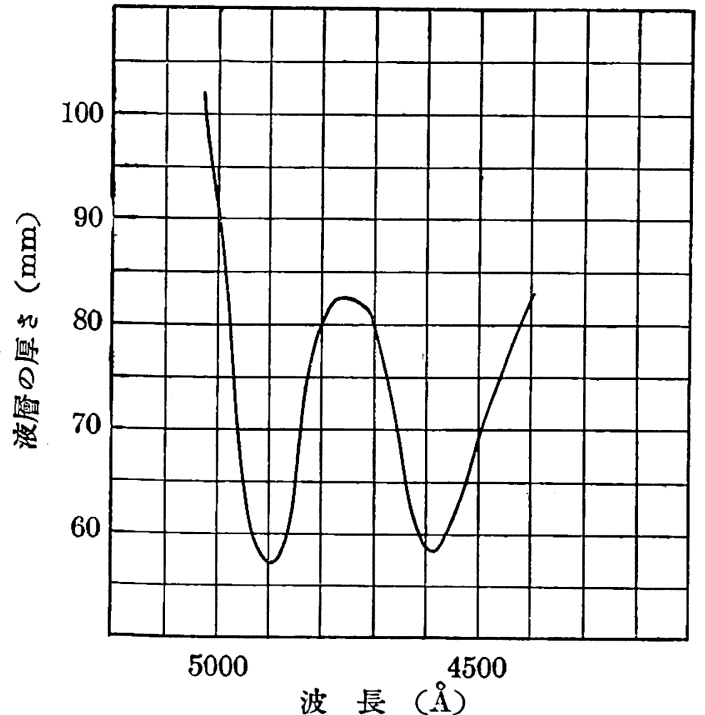

$\begin{array}{cll}\text { 液層厚さ } & \text { 第一吸收帶 } & \text { 第二吸收帶 } \\ 75 & 4970-4825 \AA & 4680-4450 \AA \\ 70 & 4955-4830 & 4655-45 C 0 \\ 65 & 4940-4840 & 4635-4520 \\ 60 & 4935-4860 & 4610-4550\end{array}$

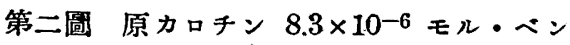
ゾール溶液の吸收曲線

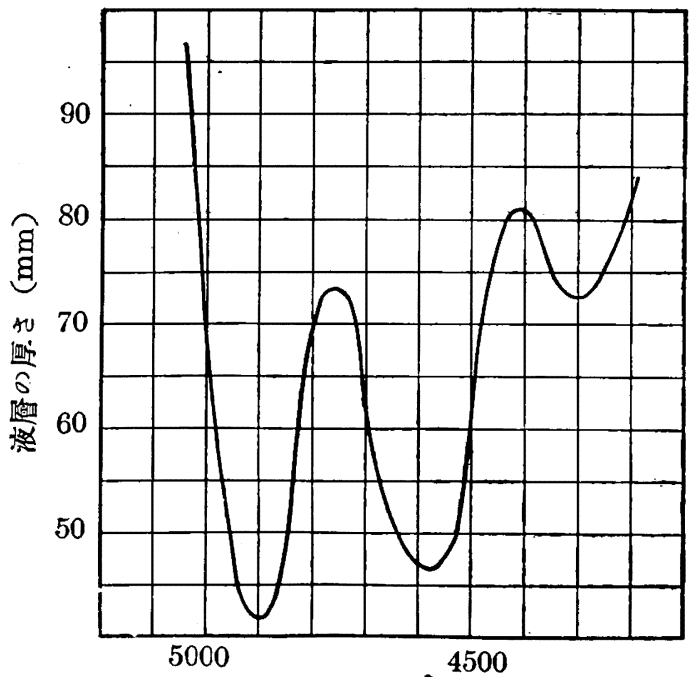

波 長 ( 
同時に是色反應を行はざる純カロチン $8.3 \times 10^{-6}$ モル・ベンゾール溶液に就ての測定結果は次の如し 第二表 原カロチン $8.3 \times 10^{-6}$ モル・ベンゾール溶液の吸收帶 (第二圖)

$\begin{array}{clcc}\text { 液相の厚さ } & \text { 第一吸收帶 } & \text { 第二吸收帶 } & \text { 第三吸收帶 } \\ 90 \mathrm{~mm} & 5030 \AA ⿻ 4 \\ 85 & 5025 & & \\ 80 & 5015 & & 4380-4210 \AA \\ 75 & 5010-4430 \AA & 4350-4250 \\ 70 & 5005-4800 \AA & 4720-4470 & \\ 65 & 4990-4810 & 4705-4480 & \\ 60 & 4980-4820 & 4700-4500 & \\ 55 & 4970-4835 & 4670-4510 & \\ 50 & 4955-4845 & 4640-4520 & \\ 45 & 4940-4860 & & \end{array}$

上記第一表並に第二表の結果は第一、第二圖に示す吸收曲線は网者㱠んど同樣なり

（2）棕橍油ベンゾール溶液よりアルコールにて抽出せし色素のベンゾール溶液の吸收曲線

前實驗同樣に棕閩油 $3 \mathrm{~g}$ をベンゾール $30 \mathrm{cc}$ に溶解し之に白土（小戸大澤白土） $5 \mathrm{~g}$ を加へて吸著呈色せ しめ同一方法に依りアルュールにて色素を抽出しベンゾール溶液を作り其色相を前實驗同樣にして其吸收帶を 湘定す同時に原棕閩油に就ても同濃度の色相として其吸收帶を測す

第三表 棕櫊油一白土一アルコール抽出色素ベンゾール溶液の吸收带（濃度 $8.3 \times 10^{-6}$ モル・カロチンベンゾール溶液と咯同一) (第三圖)

\begin{tabular}{cll|ccc} 
溶層厚さ & 第一吸收帶 & 第二吸收帶 & 溶層厚さ & 第一吸收帶 & 第二吸收帶 \\
$100 \mathrm{~mm}$ & $5015 \AA$. & & 75 & $4960-4805 \AA$ & $4670-4485 \AA$ \\
90 & $4990-$ & 70 & $4940-4835$ & $4640-4490$ \\
85 & $4980-4750 \AA$ & $4690-4455 \AA$ & 65 & $4930-4860$ & $4630-4540$ \\
80 & $4970-4790$ & $4680-4470$ & & &
\end{tabular}

$\begin{array}{lll}\begin{array}{c}\text { 溶䚄厚さ } \\ 100 \mathrm{~mm}\end{array} & \begin{array}{c}\text { 第一吸收帶 } \\ 5065 \AA \text { 第二吸收帶 }\end{array} & \text { 第三吸收帶 } \\ 90 & 5040-4350-4330-4200 \AA \\ 80 & 5035-4300-4230 \\ 75 & 5010- & \\ 70 & 4985-470 \AA \\ 65 & 4960-4760 \AA & 4720-4430 \AA \\ 60 & 4975-4780 & 4700-4445 \\ 55 & 4965-4805 & 4675-4460 \\ 50 & 4950-4825 & 4650-4485 \\ 45 & 4935-4850 & 4625-4500 \\ 40 & 4920-4860 & 4600-4530 \\ 35 & 4915-4870 & \end{array}$


第三圖 棕櫚油一白土一アルコール抽出色 素のベンゾール溶液の吸收曲線

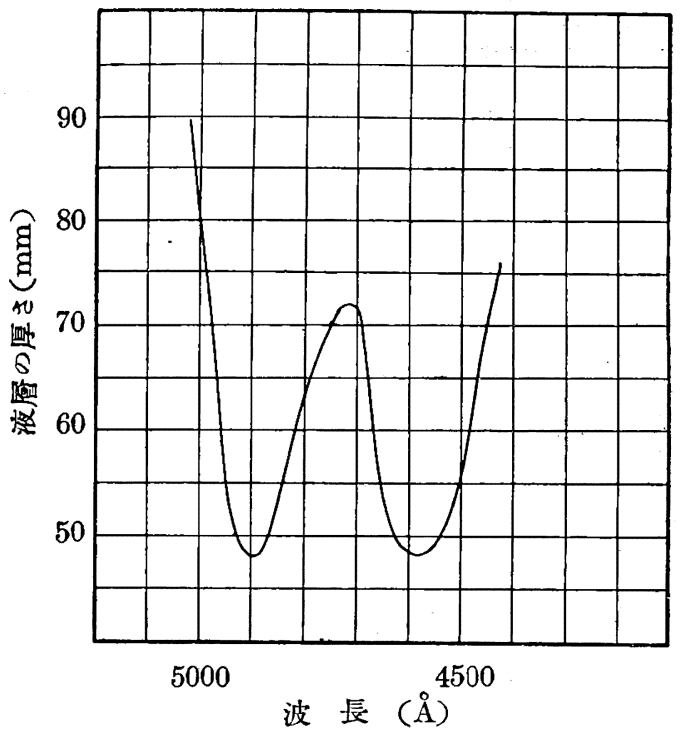

第五圖 棕櫚油一白土一アルコール抽出色 素の二硫化宸素溶液の吸收曲線

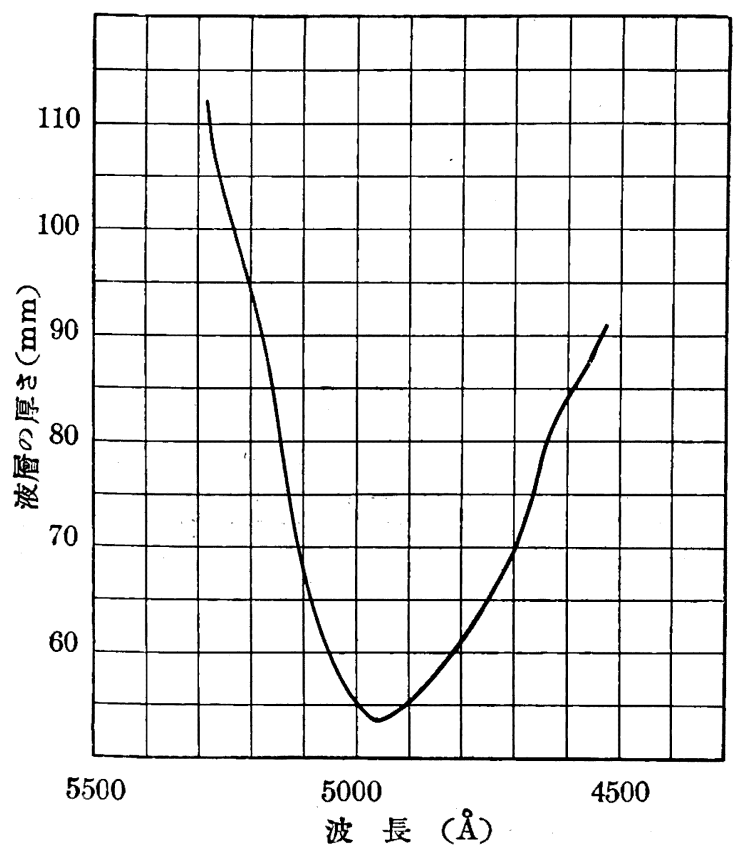

第四圖 原棕櫊油ヘンゾール溶液の 吸收曲線

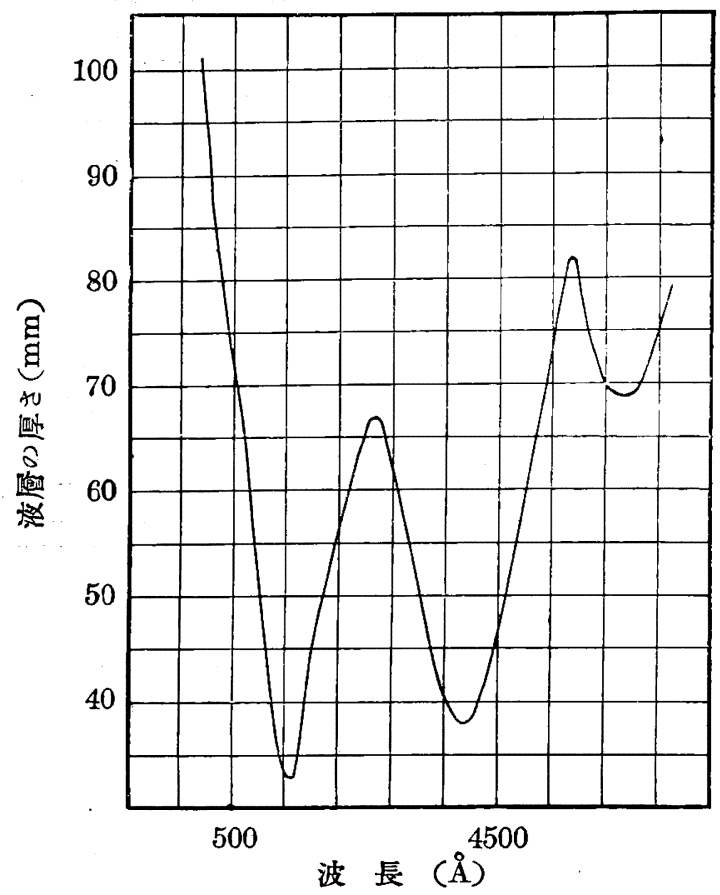

第六圖 原棕闆油二硫化宸素溶液の吸收 曲線

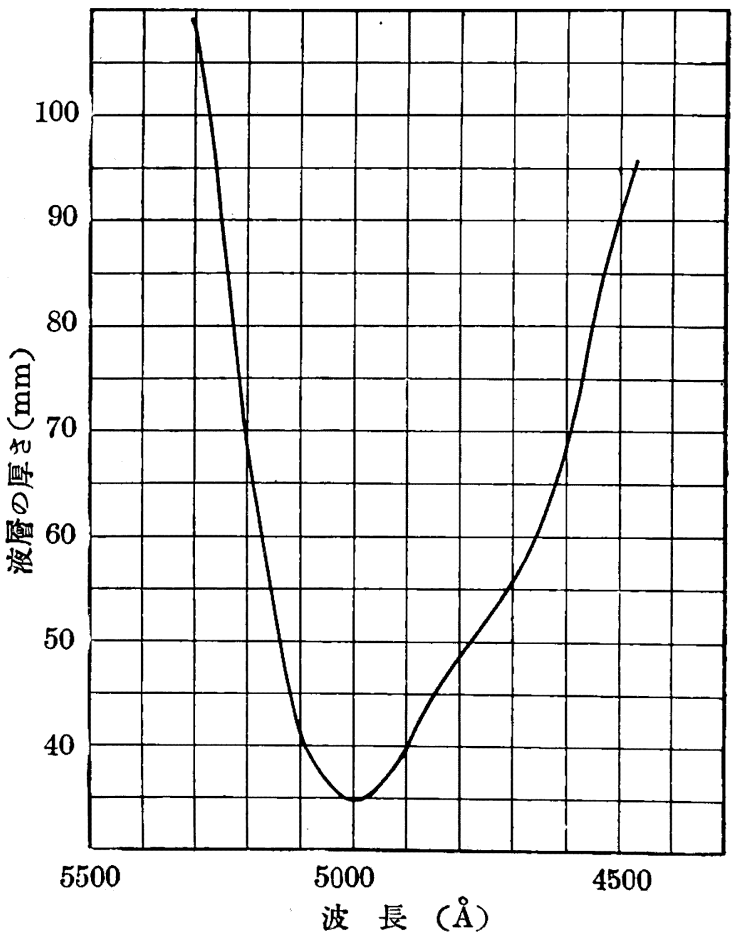


第三表、第四表の結果は第三、第四圖に示寸

之等第一圖、第二圖に於ける吸收曲線を憼察するに第一、第二吸收帽の中心は原試料溶液の吸收帶の中心と 略一致すれども抽出色素に於ては第三吸收帶を認め得ざりき又同一液層の變化に對して四收帶の變化大なると 測定に際して少しく困難を來せるは操作中小部分の色素か綳化し抽出色素溶液中に於ては原試料中のカロチン の濃度幾分小となりたるものならん要するに上記湘定結果は酸性白士に依る是色色素はアルコールに依り抽出 せられ而も其色素は少くも大部分は變化せざる原來のカロチンなる事を示し居れり

（3）二硫化炭素を溶劑とせる棕櫊油並に其呈色後アルコール抽出色素の吸收曲線

棕櫊油二硫化炭素溶液は棕櫊油 $1 \mathrm{~g}$ を二硫化炭素 $30 \mathrm{cc}$ に加へて供試料とし其溶液の 吸收帶を測定与同時 に一方に於て棕櫊油 $3 \mathrm{~g}$ を二硫化炭素 30 c.c. に溶解し乾燥小戶大澤白土 $5 \mathrm{~g}$ 名加へ充分吸著呈色せしめ後數

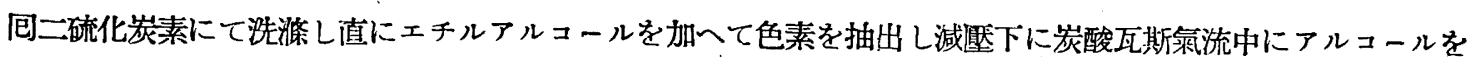
分離し後二硫化炭素を加へ前と同一の色相と其吸收帶を測定寸

第五表 棕櫚油二硫化炭素溶液並に抽出色素の二硫化炭素溶液の吸收带

液層の厚さ

$110 \mathrm{~mm}$
100
90
80
70
65
60
55
50
45
40

A. 棕櫊油二硫化崖 素溶液の吸收帶 (第六圖)

$5320 \AA-$
$5275-$
$5235-4495 \AA$
$5235-4560$
$5195-4590$
$5180-4620$
$5170-4650$
$5150-4700$
$5140-4780$
$5120-4850$
$5090-4890$

\section{液眉厚さ}

$110 \mathrm{~mm}$

100

95

90

85

80

75

70

65

60
B. 棕䦭油一白土一アルコ一 几抽出色素の二硫化宸素 溶液つ吸收帶(第五圖)
$5280 \AA$
5240
5210
$5175-4540 \AA$
$5165-4590$
$5155-4642$
$5140-4660$
$5110-4690$
$5080-4750$
$5050-4820$

上記の測定結果は之を第五、第六圆に示す如く原棕橺油二硫化炭素溶液の吸收帶の中心も亦棕櫊油呈色後抽 出色素の二硫化炭素溶液の夫れと略一致し居り呈色後抽出色素の少くも大部分は原棕櫊油溶液中の色素と同一 なる可きを示し居れり

之を要するる抽出色素の分光學的試驗の結果は該色素郎ちカロチンは酸性白土に依り呈色反應後再びアルコ ールヌはエーテル等に伡り元來のカロチンとして少くも大部分抽出せられ得る事を示寸從てカロチン含有諸物 體中より之を利用して從來より比較的簡單にカロチン色素を酸性白土に依り吸著抽出し得る事可能となれり向 之等吸著抽出苴噞に關しては改めて報告する所あるべし又抽出色素の更に決定的の證明は目下多量の棕橍油色 素を白土に吸著せしめて後アルコールにて抽出してカロチンの結晶物を得んと目下實驗中なれば之に關し更に 報告すべき像定なり

(VI) 呈色反應の機構の推定

カロチンの化學構造に就ては最近 Zürich の Karrer 氏が次の構造式を呈出し居れり (Helv. Chim. Acta. 1931, 14, 614 32 ; Chem. Abst. 1931, 25, 2733, 3660)郎ちカロチンは分子式 $\mathrm{C}_{40} \mathrm{H}_{56}$ の不饱和炭化水素なり 故にカロチンの呈色反應は脫水作用に非らざる事は明らかにしてヌカロチンは酸化せられて容易に脫色せられ 
無色に變ずる點等より考察して酸化作用に体りて呈色するものとも考へられず肝油並にヴィタミンAの呈色反 應の場合には恐らく縮合作用と推定したるもカロチンの場合は炭化水素なれば縮合に传ると考ふることも孚䓨 ならず呈色物質がアルコール、エーテル等に依り容易に抽出せられ再び原カロチンの呈色反應を反覆する點よ

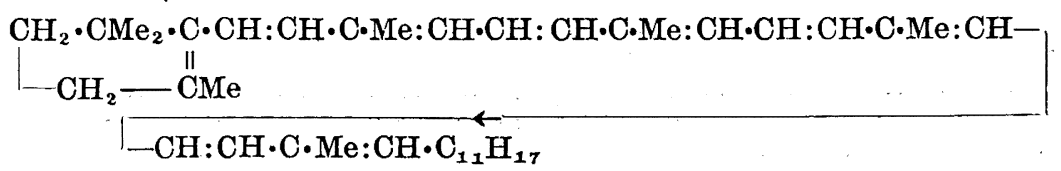

り考察して著者等は酸性白土等の此呈色反應は恐らく重合作用ならんと推定し居れり剆ちカロチンは酸性白土 に吸著せられて一部重合して高分子量に變じて毒色呈色反應を示し次に之にアルュールを注加するときは酸性 白大はアルコールを選擇的に吸著するを以て再び其色素を少くも大部分は元來のカロチンとして放出するもの と推定寸倘此虽色反應は肝油類並にヴィタミンAの呈色の場合よりも相當長時間 (數日乃至數十日間) 其青色 在保有して後漸次褐色に變化す溶劑として石油エーテルを使用する場合特に然り故に該呈色反應も實際は甚だ 複雜にして速續的に數段の化學反應を惹起せるものにして青色の呈色反應は其內最初に生じたる反應の一部な りカロチンは其構造式の示す如く甚だ複雜なる高分子量の化合物なり果して如何なる反應道程を經て如何なる 物質迄變化するかは侗今後多數の實噞を施行せざれば制明せざれども該呈色反應が諸種化學反應中恐らく重合 作用ならん事は推定し得るなり

總括

(1)标櫊油に對する青色呈色反應は酸性白土の特性なり而して此呈色反應は又酸性白土以外の脫水縮合劑た

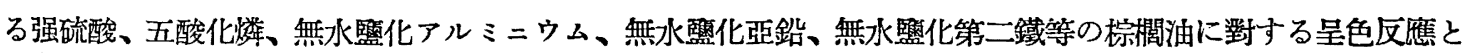
8全く同一なり

(2)棕櫊油に對する酸性白土の呈色反應はカロチンに對する呈色反應及び肝油類、ヴィタミンAに對する呈 色反應と同樣なり

（3）酸性白土屬粘土以外の陶土類其他の粘土類は一般に呈色反應を呈せず呈色するも其呈色程度微弱なり

（4）カロチン並に棕櫩油のベンゾール、二硫化炭素、石油エーテル溶液より乾燥酸性白土にてカロチンを 员著呈色せしめ後アルュール類、エーテル類又はアセトンにて吸著色素を抽出し次にアルュール類等を分離し て再びベンゾール溶液とするときは酸性白土に依り再び青色の呈色反應を爲し而も此操作を數问連續反覆する も其呈色の程度は殆んど同樣なり

（5）抽出色素のベンゾール溶液並に二硫化炭素溶液に就て更に夫等の吸收帶を゙測定せるに原カロチン溶液 と吸收帶の中心略同一なる吸收曲線を與へたり故に抽出色素の大部分はカロチンなりと推定す

（6）棕櫊油中のカロチンは酸性白土に依りて吸著呈色せしめ之をアルュール類又はエーテル類に依りて再 び大部分カロチンとして抽出し得べし之を利用して油脂類、果惯等カロチン含有物貿より酸性白土に侬る吸著 法に依り簡單にカロチンを抽出し得べし

（7）カロチンに對する呈色反應はカロチンの構造式より考へて恐らく其重合作用たるべきを推定したるる 其決定は佮將來の磍に待たざる可らず 